\title{
P04-22. Multispecific monoclonal antibodies bind to primary human macrophages and induce the production of protective chemokines, MIP-I $\alpha$ and MIP-I $\beta$
}

\author{
KL Weaver ${ }^{1}$, KK Peachman ${ }^{1}$, K Boonnak ${ }^{1}$, L Wieczorek ${ }^{1}$, GR Matyas ${ }^{2}$, \\ LM Asher ${ }^{1}$, VR Polonis ${ }^{2}, M_{\text {Marovich }}^{2}$, CR Alving ${ }^{2}$ and M Rao*2
}

Address: ${ }^{1}$ United States Military HIV Research Program, Rockville, MD, USA and ${ }^{2}$ Adjuvant and Antigen Research, Walter Reed Army Institute of Research, Rockville, MD, USA

* Corresponding author

from AIDS Vaccine 2009

Paris, France. 19-22 October 2009

Published: 22 October 2009

Retrovirology 2009, 6(Suppl 3):P50 doi:I0.1 I86/I742-4690-6-S3-P50

This abstract is available from: http://www.retrovirology.com/content/6/S3/P50

(c) 2009 Weaver et al; licensee BioMed Central Ltd.

\section{Background}

We developed a primary human monocyte-derived macrophage (MDM) HIV-1 infection model to examine human (2F5 IgM, 4E10, 2G12) and murine multispecific (WR301, WR304A, and WR320) IgM mAbs for their binding and neutralization abilities. The murine mAbs exhibit either lipid or both HIV-protein and lipid specificities. The murine and two of the human mAbs (2F5, 2G12) were also tested for binding to TZM-bl, HeLa, Jurkat, and primary $\mathrm{T}$ cells and for chemokine production.

\section{Methods}

MDM were isolated and purified from PBMC. After 5 days of growth, the cells were $>97 \%$ CD14 and CD163 positive. Binding of mAbs to cells was analyzed by immunofluorescence and flow cytometry, and the production of chemokines was measured by ELISA. To assess antibodymediated neutralization, purified 91US_1 virus was preincubated with the human mAbs for $1 \mathrm{~h}$ and then added to MDM for $3 \mathrm{~h}$. The cells were washed and cultured for $96 \mathrm{~h}$ followed by measurement of p24 in the media and in the cell lysates.

\section{Results}

The binding of murine mAbs ( $<4.8 \mathrm{pg}$ endotoxin/ $\mu \mathrm{g}$ $\mathrm{mAb}$ ) to MDM, TZM-bl, Jurkat, and primary T cells was dose-dependent and steric hinderance observed at low doses could be overcome at high doses of the antibody. A dose-dependent increase in the production of MIP- $1 \alpha$ and MIP- $1 \beta$ was obtained only from MDM, with maximum levels observed at $24 \mathrm{~h}$ post-mAb stimulation. The results were different with the human mAbs. 2G12 did not bind to MDM. 2F5 (IgM) bound to Jurkat cells and exhibited low binding $(<10 \%)$ to MDM, TZM-bl, and T cells. A productive infection was obtained in MDM with 91US_1, which could be neutralized by the human mAbs.

\section{Conclusion}

We have set up a MDM infection model to demonstrate the induction of protective chemokines and to evaluate the ability of the murine mAbs to neutralize HIV-1 in the MDM system. 